\title{
AKTIVNO PODMIĆIVANJE U HRVATSKOM SREDNJOVJEKOVNOM I NOVOVJEKOVNOM PRAVU
}

Mijo Galiot, dipl. iur.

zamjenik predsjednika Državnog sudbenog vijeća i

sudac Općinskog suda u Splitu
UDK: 343.352(497.5)

Ur.: 11. listopada 2016.

Pr.: 4. studenoga 2016.

Prethodno priopćenje

\begin{abstract}
Sažetak
Pisati o povijesti kažnjavanja znači promišljati, kritički preispitivati te bolje razumjeti suvremeni sustav kažnjavanja koji je rezultat dugoga povijesnog razvitka. Teško je odgovoriti u kojoj mjeri poimanje kažnjavanja, odnosno kazne i njezine svrhe, označava ili može označiti civilizacijsku razinu pojedinog društva. Sasvim jesigurno da se civilizacijski i kaznenopravni stav prema kazni izvodi iz niza pretpostavki: općih, kulturnih, socioloških, psiholoških, religijskih, političkih $i$ drugih čimbenika koje valja sagledavati jedinstveno $i$ u njihovoj povijesnoj dimenziji. Sam postanak kaznenog prava povezuje se s trenutkom ustrojavanja javne vlasti $i$ države. Prema povijesnom kriteriju, razlikuju se antičko (starovjekovno), srednjovjekovno te suvremeno kazneno pravo, koja su međusobno isprepletena. U ovom radu daje se prikaz i razvoj kažnjavanja počinitelja aktivnog podmićivanja u hrvatskom srednjovjekovnompravu.
\end{abstract}

Ključne riječi: srednji vijek, novi vijek, dar, mito, korist, korupcija, davanje mita, kažnjavanje, svrha kažnjavanja, kazna, kazna zatvora, novčana kazna.

\section{1. $U V O D$}

\subsection{Općenito}

Pisati o povijesti kažnjavanja znači promišljati, kritički preispitivati te bolje razumjeti suvremeni sustav kažnjavanja koji je rezultat dugoga povijesnog razvitka. Naime, „današnje krivično pravo nije rezultat napora jedne epohe ili jedne nacije“. „Suočeno s promjenama u društvu, krivično pravo modificiralo je tijekom vremena sadržaj svojih osnovnih načela i kategorija, gradilo nove institute i instrumente i pritom postajalo manje okrutno i sve ljudskije, a da nije bivalo manje uspješno u usporedbi s onim svojim fazama, koje je karakterizirala grubost, okrutnost i egzemplarnost krivičnih sankcija“. ${ }^{1}$

Teško je odgovoriti u kojoj mjeri poimanje kažnjavanja, odnosno kazne i

1 Bačić, F., Krivično pravo - Opći dio, Informator, Zagreb, 1995., str. 28. 
njezine svrhe, označava ili može označiti civilizacijsku razinu pojedinog društva, no sasvim je sigurno da se civilizacijski i kaznenopravni stav prema kazni izvodi iz niza pretpostavki: općih, kulturnih, socioloških, psiholoških, religijskih, političkih i drugih čimbenika koje valja sagledavati jedinstveno i u njihovoj povijesnoj dimenziji.

Gotovo da i nema značajnijeg autora starije i novije povijesti, koji se barem djelomično nije upustio u problematiku kažnjavanja, s time da promišljanje kažnjavanja (kazne) i njezine svrhe nije bilo pregnuće ekskluzivno pravničkih krugova. Naime, kažnjavanjem i njezinom svrhom bavili su se i ne pravnici u okruženju aktualnog vremena i prostora, vođeni vlastitim interesima, mogućnostima i motivima. ${ }^{2}$

Kao predmet pravnih, socioloških, političkih i filozofskih rasprava korupcija, u koje spada i aktivno podmićivanje kao tipično koruptivno ponašanje, kao i njezino kažnjavanje prisutni su kroz cijelu povijest. Pritom su se kroz povijest mijenjali način i svrha kažnjavanja. Štoviše, može se kazati, da povijest kažnjavanja predstavlja živi organizam koji se permanentno i postupno razvijao od prvobitnih (apsolutnih) do retributivnih (relativnih) utilitarističkih i humanističkih poimanja kazne i njezine svrhe. Drukčije izneseno, sagledavajući u cjelini „razvojni put krivičnog prava jest kretanje k racionalnijim ihumanijim shvaćanjima“. Izneseno se odnosi i na kažnjavanje aktivnog podmićivanja kao kaznenog djela, koje je s vremenom evoluiralo i u pogledu nomotehnike, i u načinu i svrsi kažnjavanja (kazne).

Sam postanak kaznenog prava povezuje se s trenutkom ustrojavanja javne vlasti i države. ${ }^{3}$ Prema različitim kriterijima moguće je sastaviti različite podjele razdoblja kaznenog prava. No, prema povijesnom kriteriju, razlikuju se antičko (starovjekovno), srednjovjekovno te suvremeno kazneno pravo (kažnjavanje) koja ne bismo trebali uzimati kao apsolutno odvojiva. ${ }^{4}$

Tako Bačić navodi da se „mora imati na umu da su u svakoj novoj fazi u izvjesnoj mjeri zastupljena načela i ideje iz prethodne faze; da između dvije faze postoji uvijek neki prijelazni stadij, koji je negdje postupniji i dulji, a negdje oštriji i radikalniji." ${ }^{\text {S }} \mathrm{U}$ ovom radu nastojat će se dati prikaz i razvoj kažnjavanja počinitelja aktivnog podmićivanja u hrvatskom srednjovjekovnom pravu.

\subsection{Srednji vijek}

Pojmovno, srednji vijek označava razdoblje između antike i novoga vijeka. Isprva je nastao u humanističkoj filologiji (media latinitas) kao oznaka za epohu u razdoblju latinskog jezika između Konstantina I. Velikoga i Karla I. Velikoga. ${ }^{6}$ Kao oznaka povijesnog razdoblja između antike i renesanse taj se pojam počeo upotrebljavati tek od kraja sedamnaestog stoljeća kada je leidenski povjesničar Georg Horn (1666. godine) prvi podijelio crkvenu povijest na tri razdoblja (stari vijek srednji vijek - novi vijek), što je u pisanju svoje opće povijesti uskoro prihvatio i

2 Iznoseći o svrsi kažnjavanja, slično Cvitanović, L., Svrha kažnjavanja u suvremenom kaznenom pravu (disertacija), Sveučilište u Zagrebu, Pravni fakultet, Zagreb, 1997., str. 1.

3 Bačić, F., op. cit. str. 29.

4 Loc. cit.

5 Loc. cit.

6 Hrvatska enciklopedija, <www.enciklopedija.hr> (20. studeni 2016.). 
Christoph Cellarius (1688. godine).

Tradicionalno se početak srednjeg vijeka određivao ,padom“ Zapadnorimskog Carstva 476. godine, ali i Konstantinovim Ediktom o toleranciji 313. godine.

Suvremene historiografije, umjesto presudnim godinama, velike epohe radije obilježavaju prijelaznim razdobljima, pa se tako početak srednjeg vijeka traži u doba Dioklecijana i Konstantina I. Velikoga, a njegov se kraj smješta u petnaesto ili početak šesnaestog stoljeća, ali se, pritom, ističe da je europsko društvo, pa i ono na Zapadu, zadržalo mnoga srednjovjekovnih obilježja i do osamnaestog stoljeća.

\subsection{Temeljna obilježja pravnih kodifikacija srednjeg vijeka}

U promatranom razdoblju razvoja kaznenopravnog sustava, u pravilu, nije bila povučena granica između kaznenog i građanskog prava, odnosno kaznenih i građanskopravnih instituta i djela, s time da su srednjovjekovne kodifikacije predstavljale jedan više-manje mehanički zbroj raznih pravnih propisa, među kojima se nalaze i brojne odredbe o kaznenim djelima i kaznama, uvrštene bez nekog pravnog reda isustava.

U tim vremenima nije još uvijek u potpunosti razvijena sposobnost za dublja uopćavanja i generalizacije, pa se ni kod stvaranja inkriminacija ne polazi od teoretskog uopćavanja s obzirom na dobro koje se štiti, već se normotvorci više povode za vanjskim obilježjima ponašanja i njih unose u inkriminacije. Međutim, treba naglasiti, da srednjovjekovno pravo obiluje normama i institutima kaznenog prava kojima se inkriminiraju različita koruptivna ponašanja, a, među ostalim, i (aktivno) podmićivanje, bilo da predstavlja posebnu inkriminaciju ili sastavni dio nekoga drugog kaznenog djela.

U izloženom, u ovom dijelu, dat će se prikaz te analiza svjetskih i domaćih pravnih propisa koji su bili ključni u to doba, a koji su svojim sadržajima bitno utjecali na razvoj i nastanak suvremenoga kaznenog prava.

\section{HRVATSKO SREDNJOVJEKOVNO PRAVO}

\subsection{Uvodno}

Hrvatsko srednjovjekovno pravo, koje je „formirano“ pod utjecajem prije svega rimskog i germanskog prava, prvotno je bilo običajno, da bi potom bilo kodificirano pretežno zakonicima i statutima u priobalnom dijelu, a kroz povlastice u kontinentalnom dijelu Hrvatske. Slično o tomu navodi i Šilović analizirajući razvoj krivnje u hrvatskom srednjovjekovnom kaznenom pravu (u Vinodolskom zakoniku, Poljičkom, Grbaljskom, Trsatskom, Dubrovačkom, Hvarskom, Kotorskom, Šibenskom, Trogirskom, Paškom, Splitskom i Skradinskom statutu te statutima Grada Zagreba od 1242. i 1266.). ${ }^{7}$ Naime, zaključio je da je rimsko-germansko, a posebno austrijsko pravo bilo od odlučnog „dojma“ na razvoj kaznenog prava u Hrvatskoj i

7 Šilović, J., O razvoju krivnje u hrvatskom kaznenom pravu, JAZU, Zagreb, 1912., str. 146. 
Ugarskoj, premda kako kaže, nikada nije formalno recipirano. ${ }^{8}$ Nadalje, isti je autor naveo da ,razlog tome valja tražiti u činjenici, što do apsolutizma nije u Hrvatskoj ni u Ugarskoj, osim Vojne krajine, bilo sustavnog kaznenog zakona, nego se kazneno pravo sastojalo od pojedinih zakonskih članaka, od običajnog prava i prakse“.

Za ovo razdoblje „kodificiranja“ također je karakteristično da nije bila povučena nedvojbena granica između kaznenog, građanskog i upravnog prava, odnosno kaznenih, građanskopravnih i upravnih instituta i djela. Dakle, odredbe normativa hrvatskoga srednjovjekovnog prava nisu posebno razrađene i odijeljene po pojedinim pravnim područjima. To je upravo dovelo do otežane analize ovih normativa, jer u nekim slučajevima nije bilo moguće bez sumnje utvrditi radi li se o kaznenoj ili građanskoj ili upravnoj regulaciji, te, u vezi s tim, radi li se o kaznenom djelu i kažnjavanju počinitelja u kaznenopravnom smislu ili stegovnoj kazni ili upravnoj mjeri koje su dio stegovnog ili upravnog postupka.

Dakle, s pravno-tehničkog aspekta, a imajući u vidu kompoziciju i sistematiku, slobodno se može kazati, da su hrvatski srednjovjekovni normativi, u pravilu, predstavljali jedan više-manje mehanički zbroj raznih pravnih propisa, među kojima se nalaze i brojne odredbe o kaznenim djelima i kaznama, uvrštene bez ikakvog pravnog sustava, a da je hrvatsko srednjovjekovno pravo pretežno bilo analitičko i kazuističko. ${ }^{9}$ Drukčije izneseno, za svaki pojedini slučaj i prema vanjskim obilježjima odnosno vanjskoj strani ponašanja određivala bi se posebna norma. Potonje se odnosi i na opise pojedinih kaznenih djela, pa i djela podmićivanja.

Tomu valja ponoviti i ono što je Bačić iznio analizirajući staro rimsko pravo s pravno-tehničke strane, a što je, po njegovoj ocjeni primjenjivo i na domaće srednjovjekovno pravo. Naime, on ističe: ,u tim vremenima ne postoji još razvijena sposobnost za dublja uopćavanja i generalizacije, pa se ni kod stvaranja inkriminacija ne polazi od teoretskog uopćavanja s obzirom na dobro koje seštiti, već sezakonodavac više povodi za vanjskim obilježjima ponašanja i njih unosi u inkriminacije“. ${ }^{10}$

U svakom slučaju, analizom normativa tog razdoblja, a primjenom pozitivnog kaznenog prava, može se kazati da je hrvatsko srednjovjekovno pravo bez sumnje obilovalo normama kaznenog prava, kojima su, među ostalim, bile regulirane i različite koruptivne inkriminacije, pa i inkriminacije podmićivanja, bilo aktivnog ili pasivnog, bilo kao samostalno kazneno djelo ili kao dio nekoga drugog kaznenog djela. Iako, ovdje, opreza radi, po mišljenju autora, valja skrenuti pozornost i na jedno promišljanje Margetića, koji je, vršeći prikaz i analizu srednjovjekovnog prava, često znao istaknuti: „proučavati pravne institute srednjeg vijeka primjenom modernih pravnih pojmova katkad zavarava jer se time, kako one kaže, dobiva posve iskrivljena slika srednjovjekovnog pravnog shvaćanja."11

Stoga će se u ovom dijelu rada dati prikaz i analiza kaznenopravnih normi kojima su bile regulirane (koruptivne) inkriminacije aktivnog podmićivanja u nekim, po autoru, značajnijim kodifikacijama toga vremena po pitanju kaznenog prava. U

8 Ibid., str. 176.

9 Ibid., str. 157.-165. i 171.-173.

10 Bačić, F., op. cit., str. 31.

11 Galović,T., Vinodolski zakon u Petrović, Z. A. (ur.), Suzbijanje korupcije u Hrvatskoj u srednjem vijeku, Udruga kultura i etika, Zagreb, str. 17. 
važne izvore hrvatskoga srednjovjekovnog prava spadali bi: Zlatna bula ili Povlastica Gradecu, Vinodolski zakonik te Splitski, Riječki, Zadarski, Lastovski, Korčulanski, Dubrovački, Senjski, Krčki, Iločki, Kastavski i Creski statut. Naime, upravo ovi statuti sadrže inkriminacije koje su svojim obilježjima, mogli bismo reći, najbliže današnjoj regulaciji kaznenog djela davanja mita, zbog čega ih je autor i odabrao kao predmet analize.

\subsection{Vinodolski zakon ili zakonik}

Zakonik je najstariji i najznačajniji hrvatski srednjovjekovni pravni spomenik, a ujedno i najstariji popisni pravni običaj koji za hrvatsku kulturu i povijest ima ključno značenje. ${ }^{12}$

Donesen je, odnosno kodificiran, 6. siječnja 1288. godine u Novom Gradu (današnjem Novom Vinodolskom). ${ }^{13}$ Razlog njegova donošenja proizlazi iz proemije odnosno predgovora samoga zakonika. Zadaća mu je bila utvrditi, sabrati i prilagoditi prava i dužnosti u pisanoj formi između kmetova i feudalnog gospodara, jer su se pojavili problemi i dvojbe oko tumačenja „starih dobrih zakona“ odnosno nepovrijeđenih i prokušanih zakona koji su se prenosili s koljena na koljeno. ${ }^{14}$

Promatrajući s društvenog aspekta priprema i donošenja Vinodolskog zakonika „ogledalo“ i prijepora koji su se tada javili između viših i nižih slojeva s područja Vinodola. ${ }^{15}$ Naime, s jedne strane, feudalci su tim zakonikom htjeli izboriti što bolji status nad pučanima i seljacima, dok je, s druge strane, običan puk htio ograničiti samovolju kneza i privilegiranih feudalnih staleža.

Pravno gledano, u zakoniku je posebno bilo zastupljeno kazneno i obvezno pravo, među kojima se posebno ističu norme koje govore o ovlastima kneza, ustroju vinodolske općine i njezinu funkcioniranju, kao i o položaju Crkve. Pritom,

12 Galović, T., op. cit., str. 11. i Margetić, L., Ususret 700. obljetnici Vinodolskog zakona, Zbornik Pravnog fakulteta Sveučilišta „Vladimir Bakarić“" u Rijeci, god. 8, 1987., str. 1. O tomu tko je vladao na širem kvarnerskom području u VII. i dalje, do XI. stoljeća (problemi vlasti Bizanta), genezi vinodolske općine i tomu što su kmetovi Vinodolskog zakonika vidjeti: Margetić. L., Noviji pogledi na stariju povijest Vinodola, Krka i Senja, Zbornik Pravnog fakulteta Sveučilišta „Vladimir Bakarić" u Rijeci, god. 8, 1987., str. 1-19.

13 Današnji tekst Vinodolskog zakonika prijepis je iz druge polovice 16. stoljeća, a sadrži 14 pergamentnih listova veličine 24,3×16,5 cm i čuva se u Zbirci rukopisa i starih knjiga Nacionalne i sveučilišne knjižnice u Zagrebu (signatura: R 4080), pri čemu su za sada nepoznati možebitni stariji prijepisi kao i sam izvornik. Jezik je zakona starohrvatski, čakavski i ekavski, odnosno filološki preciznije čakavsko-crkvenoslavenski amalgam. U samom zakoniku jezik se izravno naziva hrvatski, što je jedna od najranijih potvrda hrvatskog jezičnog etnika uopće - tako Galović, T., op. cit., str. 15.

14 Galović, T., op. cit., str. 14. S tim u vezi, Milović ističe da je opći zadatak krivičnog prava i u najdavnijoj prošlosti, kao i danas, bio: zaštita određenog društva, odnosno postojećeg poretka vidjeti šire o općim kaznenopravnim institutima kroz prizmu regulacije Vinodolskog zakonika u: Milović, Đ., Opći krivičnopravni instituti u svjetlu propisa Vinodolskog zakona, Zbornik Pravnog fakulteta Sveučilišta u Rijeci, 1981., str. 39-48.

15 Tadašnje vinodolsko društvo bilo je vrlo slojevito, a činili su ga kmetovi, plemeniti ljudi, svećenici i svi drugi ljudi. Općinske službenike predstavljali su: satnik, grašćik i busović. Satnik je stajao na čelu grada, grašćik je bio u statusu državnog službenika, a busović pozivač. 
neke odredbe u samovoljnom i prekomjernom kažnjavanju ograničavaju i samog kneza.

Kaznena djela su opisana kazuistički, što je predstavlja pravilo promatranog pravnog razdoblja, pri čemu su kazne pretežno novčane, što samo po sebi govori i o stupnju ekonomskog razvoja dotičnog društva. ${ }^{16}$

Sagledavajući sa suvremenog kaznenopravnog aspekta, zakonik nigdje izrijekom ne spominje podmićivanje, bilo aktivno ili pasivno, kao jedan od oblika koruptivnog ponašanja.

Međutim, valja navesti nekoliko važnijih odredbi koje ograničavaju samovolju feudalnog gospodara, crkvenih struktura i drugih državnih činovnika te utvrđuje njihova prava i dužnosti. Kršenjem tih reguliranih obveza može se smatrati svojevrsnom zloporabom položaja i ovlasti, a davanje tim osobama iznos veći od propisanog kao davanje mita, odnosno primanje višeg iznosa od reguliranog primanjem mita. Tako je zakonikom, u članku 1. i 2. precizno regulirano što pripada biskupu, a što pomoćniku svećenika pri posveti određene crkve, a što je onemogućilo bilo kakve druge dodatne zahtjeve odnosno zapriječilo kakva druga davanja ili obećanja izvan propisanog. ${ }^{17}$

U skladu s odredbom članka 5. zakonika ako knez dođe u neku vinodolsku općinu (grad), ondje može uzeti ili narediti da se kmetovima uzme stoka kako bi se sa svojom obitelji mogao prehraniti dok boravi u Vinodolu, no za tu stoku treba platiti naknadu u svakom slučaju.

Isto tako, zakonik, odredbom članka 48. određuje da niedan pristav ne more veće vzeti razvi 10 soldi(ni) od najveće $p$ (ravd), a najveća pravda od riči $k$ godi, ka e vridna najveće solidni 40, a od naimanšepr(avd)e, ka e takoe solidni 40, a od toga niže doli solidni 5 .

Dakle, citiranom zakonskom odredbom regulirano je koliko pristav može uzeti za svoju sudačku dužnost. To bi značilo, ako bi mu netko dao više od toga, da bi se, u biti u tom slučaju radilo o svojevrsnom davanju mita. ${ }^{18}$

I krajnje, valja spomenuti i da je odvjetnicima bilo zabranjeno primiti nagradu veću od one propisane zakonikom (čl. 54.).

U izloženom se može zaključiti da je Vinodolski zakonik mnogostruko važno

16 Galović, T., op. cit., str. 17.

17 Članak 1. u izvornom tekstu glasi: „Najprvo, da ako ka od crikav općinskih s Vinodola imaju se kerstiti vola ih bude kerstiti g(ospo)d(i)n biskup, v koibiskupiiestcrikav rečena - nimaimiti od keršćenja rečenoga navećevernezbenetačkih solidni 40, tr. 1 obedtr 1 večeru, a navlašćno od onih, ki učine tu crikavkerstiti (stavak 1.); žakanubo, ki za biskupom stoi v toi istoj crikvi, zove se hrvatski malik, a vlaški macarol, nimaimiti od toga istoga keršćenjanevećebolanč 15 vernezbenetačkih. Dotle, člankom 2. regulirano je da „Ošće: zverhcrikav, opatii vola molstirov općinskih rečenih g(ospo)d(i)n biškup ne more položiti vola vzeti ali zapovidati, neveće ono, ča bi otili dati kaštaldi tih istih crikav nema svoju volu dobru." Vinodolski zakonik, dostupno na <https://www.pravo.unizg.hr/_.../Vinodolski_zakonik.pdf>, 19. studeni 2016., str. 146.

18 Pristavi u doba Vinodola obavljali su poslove suđenja. Tako i Lukanović-Ivanišević navodi da zameci pak hrvatskoga pravosuđa sežu još u doba srednjeg vijeka, kada su u feudalnom sustavu podžupani, pristavi i tada zvani dobri ljudi, te dvorski suci bili zaduženi za rješavanje sudskih sporova, VSRH, dostupno na <www.vsrh.hr/EasyWeb.asp?pcpid=337>, 20. studeni 2016. Šre vidjeti Cvitanić, A., Pristav u Vinodolskom zakonu, Zbornik Pravnog fakulteta Sveučilišta u Rijeci, 1982., str. 69-74. 
povijesno vrelo, ne samo za pravnu povijest i razvoj instituta kaznenog prava, već i za poznavanje društvenih struktura Vinodola i crkvenog ustroja te etnološke baštine. ${ }^{19}$ Promatrajući isključivo odredbe koji se tiču sprječavanja koruptivnih ponašanja, autorovo je mišljenje da je ovaj zakonik i danas podjednako poticajan, važan i aktualan.

\subsection{Splitski ili Spljetski statut}

Statut je donesen 1312. godine, a pisan latinskim jezikom. ${ }^{20}$ Ubraja se u najznačajnija ostvarenja našega srednjovjekovnog zakonodavnog stvaralaštva, a njegova temeljna zadaća ogleda se ponajprije u nastojanju da se gradu osigura stručna, nepristrana i nadzirana uprava od koje je prema srednjovjekovnim shvaćanjima neodvojiva bila i sudbena vlast. ${ }^{40}$ Statut Grada Splita obuhvaća šest knjiga. Prva knjiga govori o crkvama, bogoštovanju, o crkvenim redovima i svecima. Druga knjiga regulirala je postupak izbora načelnika grada, njegovu službu, kao i službu svim gradskim službenicima, kao i prava i obveze koje su proizlazile iz službe. Građanskopravna pitanja kao i građanski postupak bili su regulirani trećom knjigom pod nazivom „O postupku u građanskim parnicama“.

Kazneno pravo bilo je sadržano u četvrtoj knjizi pod nazivom „O zločinima“, dok je peta knjiga obuhvaćala regulaciju vezano za građenje, komunalnu infrastrukturu, putove, zdence, mostove i gradnju. I najzad, šesta knjiga pod nazivom „O izvanrednim statutarnim odredbama“ uređivala je sva ona druga posebna pitanja koja nisu bila uređena prethodnim knjigama.

S aspekta suzbijanja korupcije i sukoba interesa, statut nigdje izrijekom ne spominje podmićivanje, a niti regulira kao zasebno djelo davanje mita. Međutim, valja navesti neke bitne odredbe u kojima bi se dalo prepoznati elemente nastojanja tadašnjeg normotvorca da se suzbiju sva moguća koruptivna ponašanja, pa, među ostalim, i podmićivanje. U vezi s tim, najveći broj statutarnih odredbi odnosi se na instituciju gradskog načelnika, koji je predstavljao komunu u unutarnjim i vanjskim odnosima te vodio komunalnu upravu i sudstvo. ${ }^{21}$ Takvim širokim ovlastima protuteža su vrlo stroga ograničenja koja bi se mogla podijeliti na izborna, statusna i funkcionalna. ${ }^{22}$ Naime, kršenjem tih strogih ograničenja od trećih osoba moglo bi se smatrati svojevrsnim davanjem mita, a sa strane načelnika zloporabom položaja i ovlasti, ali i možebitnim primanjem mita. I ovdje su se pojavile dvojbe o tomu bi li se radilo o mogućim odredbama upravnog ili kaznenog prava.

Prva skupina ograničenja odnosila se na minucioznu razradu postupka izbora načelnika, što bi se moglo tumačiti kao neka vrsta prethodne kontrole koja je trebala zajamčiti dovođenje prikladne osobe na čelo komunalnog upravnog aparata. U tom

19 Slično i Milović, Đ., Kaznena prava šest sjevernokvarnerskih statuta, Pravni fakultet Sveučilišta u Rijeci, 2005., str. 24.-30. U ovom radu Milović je, među ostalim, dao zanimljivu i sa znanstvenog aspekta važnu za analizu kaznenih djela protiv interesa pravosuđa.

20 Radić, Ž., Splitski statut, u Petrović, Z. A. (ur.), Suzbijanje korupcije u Hrvatskoj u srednjem vijeku, Udruga kultura i etika, Zagreb, str. 87.

21 Ibid., str. 88-89.

22 Ibid., str. 89. 
smislu, među inim, statut je odredio gornju granicu načelničke plaće uz proceduru obročne isplate, na način da se zadnji obrok isplaćivao umanjen za iznos od stotinu libara koji je zadržavan kao jamstvo za štetu što bi je načelnik ili njegovi ljudi eventualno počinili komuni ili privatnim osobama, s time da načelniku ne bi smjela biti isplaćena plaća, pa makar i u valjanim rokovima i iznosima, bez nazočnosti trojice sudaca. Pritom, dopustivost kakvih drugih davanja u korist načelnika statuom je bila izričito zabranjena.

Druga skupina ograničenja odnosila su se na načelnikovo poslovanje. Tako je prema statutu načelnik bio dužan nepristrano postupati prema svima, to jest da neće prijateljima pogodovati niti neprijateljima škoditi; zabranjeno mu je bilo održavati privatne odnose i družiti se s građanima; primati privatne darove te je vlastitom imovinom odgovarao za štete koje bi kome prouzročio prekoračenjem svojih ovlasti. ${ }^{23}$

Pored iznesenog, Splitski statut uređivao je institut naknadnoga sindikalnog nadzora nad radom načelnika. Posebno je važno ukazati da se zadatak trojice sindika splitskog načelnika sastojao u tomu da su nakon isteka načelničkog mandata tijekom sljedećih osam dana morali pribaviti i razmotriti izvješće o radu načelnika i njegovih suradnika. Oni su raspolagali i kaznenim ovlastima koje su obuhvaćale i mogućnost oduzimanja nezakonite dobiti i izricanje novčane kazne u njezinu dvostrukom trajanju. Osobito je važno navesti da općenito opisana pravna ograničenja mutatis mutandis vrijede i za sve druge službenike, odnosno dužnosnike splitske komune, među kojima su i vijećnici, suci, savjetnici, komunalni javni bilježnici i drugi javni službenici.

Isto tako, prema statutu, u donošenju presuda nisu mogli sudjelovati kao suci i savjetnici rođaci parničara. Štoviše, u takvim prilikama vrijedi standard prema kojemu ,nitko ne smije u toj stvari suditi tko bi od toga mogao imati vlastitu korist ili vlastitu štetu“. ${ }^{24}$ Slično tomu, ne smije sudjelovati u donošenju presude onaj tko bi bio odvjetnik u sporu, kao ni onaj tko bi u istom sporu svjedočio, osima ako bi posvjedočio da nema saznanja o predmetu spora. I najzad, ukazati je i na knjigu četvrtu, glavu 56. Splitskog statuta, pod naslovom „O lupeštinama ozloglašenih službenika“". ${ }^{25}$ Prema toj odredbi upravitelj ili službenik grada Splita koji primi nešto od nekog pojedinca suprotno statutarnim odredbama ima se kazniti s 25 libara, pod uvjetom da je taj dar vrijedio više od 10 solida, odnosno sa 10 libara i dvostrukim vraćanjem onoga što je primio, ako je vrijednost manja od 10 solida.

Iako više upravnopravne prirode, predviđeno statutarno djelo sadrži određene elemente i obilježja kaznenog djela zloporabe položaja i ovlasti, ali i kaznenih djela primanja mita „ozloglašenog“ službenika, ali i davanja mita treće osobe koje podmićuju službenika splitske komune, ako uzmemo u obzir suvremeno važeće (domaće) kazneno zakonodavstvo. Analizom navedenih statutarnih odredbi, zaključiti je, da je jedna od fundamentalnih intencija stvaralaca Splitskog statuta bila jasno odvojiti javni ili opći od partikularnog interesa, te izgraditi učinkovit legislativni okvir

23 Ibid., str. 90.

24 Ibid., str. 94.

25 Statut grada Splita, Frangeš, I. (ur.), Književni krug Split, Split, 1998., str. 655 i Statut grada Splita: srednjovjekovno pravo Splita, Rismondo V. (ur.), Književni krug, Split, 1985., str. 207 i 208. 
koji bi pravovremeno indicirao, ali i učinkovito spriječio i suzbio svako koruptivno ponašanje pa i pojavu podmićivanja (kao tipičnog takvog ponašanja) ponajprije pripadnika, mogli bismo kazati, javnoga sektora splitske komune. Kazne su bile pretežno novčane prirode u smislu određenog novčanog iznosa koji se morao dati ili u vraćanju dvostrukog iznosa primljenog "mita".

\subsection{Korčulanski statut}

U prvi red vrlo značajnih pravnih i pravno povijesnih spomenika slavenskih naroda te kulturnih društva općenito ide i Korčulanski statut za koji se kaže da je iz 1214. godine. ${ }^{26}$ Nastao je s namjerom stanovništva otoka Korčule da se „obrane“ od pretenzija (kneza) Mletačke Republike svoju otočnu zajednicu u kojoj bi prevaga bila na javnim (komunalnim) interesima i zakonitosti, a ne na partikularnim interesima kneza i njegove obitelji. ${ }^{27}$ U vezi s tim, Radić zaključuje da je nastojanje korčulanske zajednice da uspostavi pravni okvir za poštenu i djelotvornu lokalnu vlast zacrtano već u svečanom statutarnom prohemiju, a da se to nastojanje konkretizira i u odgovarajućim normativnim statutarnim odredbama, od kojih se većina bavi pravosuđem, središnjom javnom dužnosti u srednjovjekovnom razdoblju. ${ }^{28}$ Prva verzija statuta donesena je 1265. godine, iako se pretpostavlja da je postojala i ranija verzija iz 1214. godine, budući da statut iz navedene kasnije godine započinje „Potvrda i dopuna statutarnih odredbi grada i otoka Korčule učinjena za vrijeme kneza Marsilija Zorzija, mletačkog plemića i višeg dubrovačkog kneza. ${ }^{29}$

Prva verzija statuta obuhvaćala je uvod i pedeset tri glave, čemu je dodano još dvadeset glava dodatkom statuta iz 1271 . godine. ${ }^{30}$

Iako obiluje kaznenim odredbama, poglavito onim kojima se nastojalo spriječiti i suzbiti zloporaba položaja i ovlasti te podmićivanje, ali i druge pojavne oblike koruptivnog ponašanja, statut nema odredbu koja bi izričito svjedočila o aktivnom podmićivanju kakvog ima u vidu suvremeno kazneno pravo. No, mnoge odredbe upućuju odnosno sadrže određena obilježja koja su inkompatibilna današnjoj regulaciji toga kaznenog djela, a čiji će se prikaz i analiza dati u nastavku ovoga rada.

Tako statut, u glavi 24., pod naslovom „O izboru sudaca i službenih osoba“, među ostalim, određuje da i suci moraju suditi pravedno prema gradskim statutarnim odredbama potisnuvši mržnju, naklonost, strah (i odbivši) mito, a gdje ne bude pisanih

26 Iz Vijesti, Arhivski vjesnik, 31/1987, str. 180., <www.hrcak.srce.hr/file/179101>, 20. studeni 2106.

27 O rukopisima ovog statuta vidjeti Strohal, I. (nap.), Statuti primorskih gradova i općina, Jugoslavenska akademija znanosti i umjetnosti, Zagreb, 1911., str. 57-60., <booksnow1. scholarsportal.info/.../statutiprimorski00stro/ statutiprimorski00stro.pdf>, 19. studeni 2106. , Cvitanić, A. (prir. i prev.), Šeparović, Z. (ur.), Korčulanski statut: Statut grada i otoka Korčule iz 1214., Zagreb - Korčula, JAZU, Pravni fakultetu u Zagrebu i Splitu, Skupština Općine Korčule i Grafički zavod Hrvatske, 1987., Uvod - XVIII.

28 Radić, Ž., Korčulanski statut u: Petrović, Z. A. (ur.), Suzbijanje korupcije u Hrvatskoj u srednjem vijeku, Udruga kultura i etika, Zagreb, str. 24.

29 Ibid., str. 23.

30 Prijatelj, K. (ur.), Korčulanski statut: Statut grada i otoka Korčule (1214-1265), Književni krug, 1995., str. 22. 
statutarnih odredaba, prema svojoj dobroj i čistoj savjesti i to u svakoj stvari o kojoj budu smatrali da treba donijeti presudu. ${ }^{31}$

Iznoseći o službenicima u glavi 84., normotvorci ovog statuta izričito reguliraju: „Isto tako određujemo i naređujemo da se ni jedan čelnik, poljšćik, ${ }^{32}$ pudar $^{33}$ niti drugi koji službenik koji je, ili će ubuduće biti, nadređen ovčarima i pastirima, ne usudi i ne drzne primiti neki dar, tj. životinju, vunu i sir od nekog drugog čelnika ili od pastira (kao mito) pod prijetnjom globe od pet pepera za svaki prekršaj bilo kojem od tih službenika koji bi postupio suprotno. Dakle, iz iznesenog, zaključiti je da bi prvi dio statutarne odredbe regulirao primanje mita, a drugi davanje mita. Potencijalni počinitelj primanja mita mogao bi biti bilo koji službenik, a davanja mita čelnik, ovčar ili pastir. Kazna je bila isključivo novčana. Također, zanimljivost se ogleda i u tomu da se postojanje djela podmićivanja i počinitelja mogla dokazati samo na temelju iskaza dvaju svjedoka, i to, kako statut, navodi „vjerodostojnim“ svjedocima. Kako se, u pravilu, radi o izrazito koluzivnim kaznenim djelima, po ocjeni autora, bilo je teško očekivati ispunjenje ovog pravnog standarda dokazivanja kakvog ima u vidu predmetna statutarna odredba.

Isto tako, statut je, u članku $139 .{ }^{34}$ odredio maksimum nagrade koju je smio primiti komunalni odvjetnik ili bilo koji drugi zastupnik. Tako, prema navedenoj zakonskoj odredbi, komunalni odvjetnik ili zastupnik ne može primiti nagradu osim jednoga groša, pod prijetnjom kazne iz zakletve. Ako uzme neku veću nagradu u ime plaće, mita ili dijela, neka plati globu dvostruke vrijednosti svega što je primio iz prije navedenih razloga. Polovica novčane kazne pripada Komuni, a druga polovica prijavitelju, samo ako je to dokazano dvama vjerodostojnim svjedocima. A osim toga neka bude lišen odvjetničke službe tih šest mjeseci, što se odnosi na sudovanja ili presuđivanja u tuzemstvu. Sve ono što je izneseno vezano uz podmićivanje u članku 84. Statuta vrijedi i za komunalne odvjetnike i druge zastupnike u pogledu potencijalnog kruga počinitelja, kazne, ali i pravnog standarda dokazivanja ovog djela, koji bi, imajući u vidu suvremene regulacije, imao određene elemente kaznenog djela pasivnog podmićivanja. Iznimka je samo u tomu što se, uz novčanu kaznu, počinitelju ovog djela izriče i svojevrsna obligatorna sankcija odnosno sigurnosna mjera „udaljenja“ od obavljanja odvjetničke službe unutar korčulanske zajednice tijekom ograničenoga vremenskog trajanja. ${ }^{35}$

31 Slično i Radić, Ž., Korčulanski statut u Petrović, Z. A. (ur.), Suzbijanje korupcije u Hrvatskoj u srednjem vijeku, Udruga kultura i etika, Zagreb, str. 26. Cjelokupan sadržaj ove odredbe vidjeti u: Cvitanić, A. (prir. i prev.), Šeparović, Z. (ur.), Korčulanski statut: Statut grada i otoka Korčule iz 1214., Zagreb - Korčula, JAZU, Pravni fakultet u Zagrebu i Splitu, Skupština Općine Korčule i Grafički zavod Hrvatske, 1987., str. 15. O shvaćanju pravednog suđenja i nasljeđivanju govorio i Hesiod u svom epu „Poslovi i dani“, kada je kazao: „I Pravda podiže glas kad je vežu suci koji su glasni mita i nepravu presudu daju - prema Margetić, L., Opća, str. 30 i Heziod, Poslovi i dani, prijevod Alberta Bazale, Matica Hrvatska, Zagreb, 1970. (preuzeto iz Bartulović, Ž., Opća povijest prava i države, Pravni fakultet Sveučilišta u Rijeci, Rijeka, 2014., str. 36.).

32 Službeni procjenitelji poljskih šteta, osobito žita u korčulanskoj zajednici.

33 U korčulanskoj zajednici čuvari polja i vinograda te prijavitelji šteta u njima.

34 Glava CXXXIX. pod naslovom „Koliko treba dobiti komunalni odvjetnik“.

35 Slično i Radić, Ž., Korčulanski statut...., str. 29. 
Regulativa Korčulanskog statuta o suzbijanju zloporabe ovlasti i koruptivnih ponašanja zaokružena je upravo reformacijama odnosno svojevrsnim novelama prvotnog zakonskog teksta, koje su uglavnom donesene u 15. stoljeću. ${ }^{36}$

Reformacijom je u glavi 108. pod naslovom „Nagrada odvjetnika i zastupnika“, opetovana zabrana primanja „mita“ odvjetnika i drugih zastupnika za odvjetničke usluge povrh dopuštene tarife, uz propisivanje istovjetnih „,kazni“. ${ }^{37}$

\subsection{Dubrovački statut}

Pisani pravni poredak Dubrovačke Republike počivao je na statutu iz 1272. godine i sedam naknadno donesenih zakonskih zbirki (Statut carinarnice, Knjige svih reformacija, Stonske odredbe, Zelene knjige, Žute knjige, Lastovski statut i Mljetski statut). U ovom dijelu posebnu pozornost će se dati samom Dubrovačkom statutu. ${ }^{38}$

Kada Dubrovački statut iz 1272. godine u svome uvodu „kaže“ da on služi pravdi, a ona „učvršćuje zemlje, povećava i umnaža gradove, rađa slogu, njeguje mir, upravlja ljudima i narodima da žive miroljubivo i mirno", to nije samo lijepa, svevremena misao o ulozi prava u društvu, već su upleteni biblijski motivi i opća mjesta srednjovjekovne političke retorike, ali iz nje struji i povjerenje u snagu prava. ${ }^{39}$

Odredbe ovog statuta, kako tvrdi Janeković Romer, svjedoče o brizi za djelovanje pravnog poretka i javnih službi, a protiv korupcije, sukoba interesa, zloporabe položaja, pronevjere, utaje poreza, neisplaćivanje plaća radnicima, krađe te rodbinskog i interesnog umrežavanja. Nadalje, ista je autorica istaknula da je dubrovačka vlada poduzimala poticajne, nadzorne i kaznene mjere i institucionalnu kontrolu kako bi utjecala na savjest i postupke službenika i spriječila sukob između javnog i osobnog interesa.

Strukturalno i sadržajno promatrajući, Dubrovački statut sastojao se od osam knjiga. ${ }^{40}$ Prvom knjigom regulirane su razne povlastice i odgovornosti kneza, njegovih zamjenika i nadbiskupa ${ }^{41}$ Druga knjiga uređuje zakletve kneza, njegovih zamjenika, sudaca, članova vijeća i drugih javnih službenika. ${ }^{42}$ Treća knjiga bavi se građanskim pravom u materijalnom i postupovnom smislu. ${ }^{43}$ Obiteljsko i nasljedno

36 Loc. cit.

37 Cjelokupan sadržaj ove odredbe vidjeti: Cvitanić, A. (prir. i prev.), Šeparović, Z. (ur.), Korčulanski statut: Statut grada i otoka Korčule iz 1214., Zagreb - Korčula, JAZU, Pravni fakultet u Zagrebu i Splitu, Skupština Općine Korčule i Grafički zavod Hrvatske, 1987., str. 118.

38 Janeković Romer, Z., Dubrovački statut i druge zakonske zbirke u: Petrović, Z. A. (ur.), Suzbijanje korupcije u Hrvatskoj u srednjem vijeku, Udruga kultura i etika, Zagreb, str. 97.

39 Lonza, N. u povodu prvog izdanja Dubrovačkog statuta iz 1272. na engleskom jeziku: The Statute of Dubrovnik of 1272., <www.matica.hr/.../Dubrovački\%20statut>, 20. studeni 2016.

40 Lonza, N. (ur.), The Statute of Dubrovnik od 1272., Državni arhiv u: Dubrovniku, Dubrovnik, 2012., str. 12. Latinski i hrvatski tekst statuta sadržan i u: Šoljić, A., Šundrica, Z. i Veselić, I. (pre. i ur.), Statut grada Dubrovnika (sastavljen godine 1272.), Državni arhiv u Dubrovniku, Dubrovnik, 2002. (uvodnu studiju napisala Lonza, N.), str. 48-415. Pritom, Knjiga šesta koja sadrži kaznenopravnu materiju nalazi se na str. 325-371.

41 Lonza, N., op. cit., str. 11., Šoljić, A. i dr., op. cit., str. 83-124.

42 Lonza, N., op. cit., str. 11.

43 Šoljić, A. i dr., op. cit., str. 125-183. 
pravo regulirano je četvrtom knjigom, dok peta knjiga sadrži stvarnopravnu regulativu. ${ }^{44}$ Kaznenopravna regulacija sadržana je u šestoj knjizi, dok se pomorsko pravo nalazi u sedmoj knjizi. ${ }^{45}$ Razne ostale odredbe nalaze se u posljednjoj osmoj knjizi. ${ }^{46}$ Sublimirano izneseno, valja primijetiti da su prve dvije knjige zapravo upravnopravne prirode, da treća do pete knjige sadrže građanskopravnu materiju, dok je kaznena regulativa sadržana samo u jednoj, sedmoj knjizi.

Iako ne sadrži odredbe koje bi svjedočile o aktivnom podmićivanju kao posebnom kaznenom djelu, ipak Statut unutar određenih (više stegovnih) inkriminacija zabranjuje zloporabu službenog položaja i ovlasti, te, u vezi s tim, i primanje, odnosno davanje mita, a čiji se prikaz i analiza daju u nastavku ovog rada. Uglavnom se radi o upravnim normama s nedvojbeno elementima kaznenopravne prirode, a koje nisu smještene u kaznenom dijelu statuta, odnosno šestoj knjizi.

Već u samoj kneževoj prisezi navodi se: ,Ja, knez dubrovački, prisežem na Sveta Božja evanđelja da ću u dobroj vjeri, bez himbe i zle namisli naštetiti ovaj grad i njime upravljati prema njegovu poretku i običaju... i da ću probitke općine dubrovačke pošteno štititi. Sprječavat ću zavjere i tajne saveze... te zlodjela. Pravdu ću jednako izvršavati jačimai slabijima... S većinom u Vijeću i sa sudom suzbijat ću zle navike, a dobre promicati. I neću pomagati prijatelju niti na prijevaru škoditi neprijatelju“ “. ${ }^{47}$ U prisezi kneževih zamjenika, sudaca i odvjetnika i vijećnika izrijekom stoji da „neće uzimati ni dopuštati da se uzima mito da bi se nekome pomoglo ili naškodilo". ${ }^{48}$

Normotvorci Dubrovačkog statuta posebnu pozornost pridavali su pravosuđu koje je bilo pod posebnim nadzorom zbog očito prisutne velike mogućnosti zloporaba, jer je plaća sudaca bila mala (suce se htjelo motivirati više dužnošću koju obavljaju, nego zaradom) ${ }^{49}$ Ovo proizlazi i sadržaja same prisege sudaca i odvjetnika (članak 4. druge knjige), ${ }^{50}$ prema kojoj su bili dužni „obećati“ (prisegnuti) da neće primati nagradu ni darove od klijenata i da neće odgađati presude kako bi ostvarili dobitak. ${ }^{51} \mathrm{U}$ vezi s tim, nisu smjeli primati mito, a ako bi to netko učinio u njihovo ime, morali su sve vratiti i nadoknaditi štetu. Zanimljivo je da su i stranke u sudskim postupcima morale prisegnuti da nisu dale mito i da to nije od njih zatraženo. Izvorni tekst dijela odredbe članka 4. Glave druge pod nazivom „Prisega sudaca“ glasio je: Ja, sudac dubrovački, prisežem na sveta Božja evanđelja da ću sve postupke koji se budu vodili preda mnom, u kojima budem sudac, suditi bez himbe, prema običaju grada Dubrovnika, ako budem znao i budem siguran. Ako ne budem znao običaj, sudit ću bez himbe i zle namisli po svojoj čistoj savjesti. I neću primiti nagradu, ni dati da se

44 Ibid., str. 185-239.

45 Lonza, N., op. cit., str. 63., Šoljić, A. i dr., op. cit., str. 372-413.

46 Lonza, N., op. cit., str. 69., Šoljić, A. i dr., op. cit., str. 415-513.

47 Janeković Romer, Z., Dubrovački statut i druge zakonske zbirke u: Petrović, Z. A. (ur.), Suzbijanje korupcije u Hrvatskoj u srednjem vijeku, Udruga kultura i etika, Zagreb, str. 97 i 98.

48 Janeković Romer, Z., op. cit., str. 98., Šoljić, A. i dr., op. cit., str. 126. Vidjeti čl. 2. druge knjige Statuta u Lonza, N. (ur.), The Statute of Dubrovnik od 1272., Državni arhiv u Dubrovniku, Dubrovnik, 2012., str. 101.

49 Lonza, N., op. cit., str. 98-99.

50 Ibid., str. 103.

51 Janeković Romer, Z., op. cit., str. 99. 
primi za postupke koje ja budem imao suditi, pa ako netko za mene primio, a ja za to doznao, pobrinut ću se u dobroj vjeri i bez himbe da se to vrati. Ako me naš gospodin knez, ili tko ga bude zamjenjivao, sam ili preko svoga glasnika, pozove za potrebe Grada, ili ako čujem zvono Velikog ili Malog vijeća, poći ću ne budem li opravdano spriječen....

Isto se odnosi i na diplomatsku (poslaničku) službu, ali i na računovođe grada službenike koji su baratali općinskim prihodima.

Naime, prema statutu, ako bi netko dao novac poslanicima, bio bi kažnjen zatvorskom kaznom u trajanju od šest mjeseci, a poslanik koji bi novac primio izgubio bi službe i povlastice Republike te bi odslužio zatvorsku kaznu u trajanju od šest godina. Također, diplomati nisu smjeli zadržati diplomatske darove, osim namirnica, a nije ih zadržavala ni država nego su se prodavali na dražbi, jer su u suprotnom gubili plaću i morali su platiti kaznu u dvostrukoj vrijednosti „mita“.

I službenici koji su baratali „proračunom“ grada morali su prisegnuti da robu i novac neće zadržavati, upotrijebiti u svoju korist ni posuđivati, nego da će isključivo namjenski trošiti općinske prihode, i to ne po svojoj volji, nego po zapovijedi kneza i Malog vijeća.

U izloženom, zaključiti je da su odredbe ovog statuta predviđale vrlo stroge i visoke kazne za počinitelje koruptivnih djela, u koje, kao tipično, spada i podmićivanje. Krajnje i trajnom gubitku javne službe i svih povlastica koje proizlazile iz službe.

U vezi s prethodnim, Janeković Romer dolazi do zaključka da je: Dubrovačka politika u osvit novog vijeka uvelike se oslanjala na Cicerona i njegovu postavku o državi kao najjačoj odrednici života pojedinca, na Aristotelovoj ideji o dobru kao cilju države te na kršćanskom humanizmu i moralu. Bitna komponenta tog svjetonazora jest republikanizam, na koji se nadovezuje domoljublje, poštovanje zakona $i$ etičkih normi te odgovornost u javnom životu. Državna služba smatrala se služenjem općem dobru zajednice, a ne prilikom i oruđem za stjecanje materijalnih, društvenih i političkih prednosti. ${ }^{52}$ Pritom je citirala izvod iz jedne odluke Velikog vijeća Dubrovačke Republike iz 1429. godine o nadzoru nad službenicima, prema kojoj ,pravda i pravedno vršenje službe je najsjajnija vrlina koja stabilizira vlasti, povećava dobrobit država i pojedinaca i omogućuje mir". Također dodaje: to višestoljetno povijesno iskustvo i velika politička tradicija Dubrovačke Republike $i$ danas nosi snažnu poruku koja može biti uzor i nadahnuće političkoj realnosti Republike Hrvatske, sčime se u punini slaže i autor ovog rada.

\subsection{Lastovski statut}

Statut otoka Lastova donesen je 10. siječnja 1310. godine na javnom zboru otočana za vrijeme vladavine dubrovačkog kneza, radi kodifikacije normi običajnog prava u lastovskoj komuni te stvaranja i održavanja što razvijenijeg društva na otoku Lastovu i njegova što boljeg funkcioniranja. Sastoji se od trideset glava građanske, kaznene i upravne prirode, napisane u cijelosti na talijanskom jeziku. ${ }^{53}$

53 Dragičević Prtenjača, M., Lastovski statut u Petrović, Z. A. (ur.), Suzbijanje korupcije u 
Prema sistematizaciji svih krivičnih djela Lastovskog statuta, Rismondo ${ }^{54}$ je izdvojio posebnu skupinu kaznenih djela „lošeg vršenja službene dužnosti“, u koju su, među ostalim, spadala i naplaćivanja preko propisanog iznosa od sudaca, nepodnošenje računa o svojoj upravi od prokuratora bratovština, nevršenje službenih dužnosti kneza, sudaca, justicijara i kancelara, primanje ulja umjesto mesa od kneza, primanje na dar što se daje knezu više od propisanog.

Poput Dubrovačkog, i u Lastovskom statutu opisi kaznenih djela postavljeni su kazuistički i predstavljaju samo nastavak regulacije neke druge materije, poglavito upravnopravne prirode.$^{55}$ Isto tako, ovaj statut ne uređuje davanje mita kao zasebno kazneno djelo, promatrajući suvremeni koncept toga kaznenog djela. Međutim, neke odredbe upravnopravne prirode, mogli bismo reći, sadrže elemente toga kaznenog djela, ali i djela primanja mita.

Tako, prema glavi 124. Statuta pod naslovom „Kneževa plaća“, knezu nije dopušteno primanje darova. Analizirajući ovu odredbu, Dragičević Prtenjača navela je da predmetna odredba u sebi sadržava zabranu kao jedan od važnih elemenata kaznenopravne odredbe, ${ }^{56} \mathrm{a}$ da je suprotno ponašanje štetno i protupravno, a iz čega se vidi kaznenopravna priroda odredbe.

Nadalje, u glavi 125. Statuta pod naslovom „Knez ne smije trgovati“, zabranjeno je (pod prijetnjom kazne) davanje mita knezu, a, u suprotnom, kaznit će se s novčanom kaznom od 200 perpera svaki Lastovac, ali i knez koji je primio „mito“, pri čemu „ubrana“ kazna ide u korist lastovske komune. ${ }^{57} \mathrm{U}$ vezi s tim, Rismondo je zaključio da bi iz statutarne glave 125. proizlazilo da je i samo davanje mita (dara) knezu više od reguliranog krivično djelo za koje odgovara Lastovac darodavac, a ne samo, kako smo u prethodnom stavku naznačili, knez kao daroprimac. ${ }^{58}$

Određena ponašanja koja bi odgovarala suvremenim konceptima kaznenih djela

Hrvatskoj u srednjem vijeku, udruga Kultura i etika, Zagreb, str. 103 i 105. O svim rukopisima ovog statuta vidjeti Strohal, I. (nap.), Statuti primorskih gradova i općina, Jugoslavenska akademija znanosti i umjetnosti, Zagreb, 1911., str. 95., <booksnow1.scholarsportal.info/.../ statutiprimorski00stro/ statutiprimorski00stro.pdf $>$, (20. studeni 2016.)

54 Rismondo, V. (ur.), Lastovski statut, Književni krug, Split, 1994., str. 192-194.

55 Slično i Dragičević Prtenjača, M., op. cit., str. 107.

56 Ibid., str. 108. Izvorni tekst ove glave glasio: „Neka Lastovci budu dužni ubuduće davati kao plaću spomenutom knezu 200 škuda godišnje od po 36 groša svaku u ovim rokovima, tj. trećinu onda kada knez počne obnašati svoju službu, trećinu nakon šest mjeseci, a sav ostatak onda kada ga zamijeni nastupnik. I neka mu preko te plaće ne smiju davati kao poklon srdele ni drugu vrstu ribe, ni vino, ni ulje ni išta drugo - Preuzeto iz Rismondo, V., op. cit., str. 273.

57 Ibid., str. 109. Izvorni tekst glave 125. st. 1. glasio je: „Po nalogu presvijetlih i preizvrsnih vijećnika odlučeno je sa 7 kuglica da se presvijetlom gospodinu knezu ne smije dati ni dodijeliti u poklon više od dvije bačvice srdela, osim ako bi se dugovalo za njegovu palaču, pod (prijetnjom) kazne od 200 perpera i samom knezu i Lastovcima u korist lastovske komune, dok prema st. 2. istog članka: „Neka knez pod (prijetnjom) kazne trajnog gubitka službe i povlastica i gubitka posljednje trećine svoje plaće, od koje polovicu treba dati dubrovačkoj blagajni, a drugu polovicu prijavitelju po čijoj prijavi se doznade istina, a koji prijavitelj treba da ostane u tajnosti, ne može niti smije sam ili preko posrednika ni pod kakvim izgovorom ili smicalicom trgovati na spomenutom otoku niti na njemu obavljati bilo kakve trgovačke poslove“. - Preuzeto iz Rismondo, V., op. cit., str. 274.

58 Rismondo, V., op. cit., str. 194. 
davanja i primanja mita, kao i zloporabe položaja i ovlasti sadržana su i u glavama 20., 22. i 128. Lastovskog statuta. ${ }^{59}$

Statut, u glavi 20. „naređuje i određuje da ni jedan sudac ne smije nikamo ići piti ili jesti s nekim tko se spori pred sucima sve dok bude trajao taj spor i to pod (prijetnjom) globe od 6 groša za suca i globe od 6 groša za onog tko se spori.“ Dakle, zabranjeno je sucima jesti i piti sa strankama u sudskim postupcima dok oni traju, inače, u suprotnom, izvrgavaju se novčanoj kazni. ${ }^{60}$

Također, sucima je zabranjeno i primanje iznosa poviše iznosa vrijednosti predmeta spora, u skladu s glavom 22. Statuta. Ako bi stranka u određenom predmetu postupila suprotno ovoj odredbi, pa dala sucu mito kako bi sudio u njezinu korist, $\mathrm{u}$ tom bi se slučaju radilo o svojevrsnom počinjenju kaznenog djela davanja mita.

Zabranjen je i utjecaj kneza radi sprječavanja osoba koje se žele obratiti dubrovačkom sudu, za koje postupanje je glavom 128. statuta predviđena kazna od 100 perpera u korist dubrovačke komune. ${ }^{61} \mathrm{U}$ slučaju postupanja suprotno od reguliranog, ovdje bi se moglo raditi o svojevrsnoj zloporabi položaja i ovlasti. ${ }^{6}$

Analizom statutarnih odredbi, može se kazati da su ovom statutu ugrađene norme koje su sadržajno u većoj ili manjoj mjeri odgovarale suvremenim kaznenim djelima primanja mita, davanja mita i zloporabe položaja i ovlasti. Navedeno svjedoči i o tomu da je lastovska komuna u to doba detektirala i nastojala suzbiti koruptivna ponašanja, ali i potencijalni sukob interesa koji institut je usko povezan s korupcijom i može joj prethoditi (ali ne mora nužno predstavljati korupciju kaznenopravnom smislu). ${ }^{63}$

\subsection{Statut Grada Rijeke}

Riječki statut donesen je i potvrđen sankcijom kralja Ferdinanda Habsburškog 1530. godine. ${ }^{64}$ Napisan je na latinskom jeziku i podijeljen u četiri knjige: prva knjiga sastoji se od devetnaest glava, druga od pedeset četiri, treća od pedeset i pet i četvrta od dvadeset i jedne glave. ${ }^{65}$

59 Ibid., str. 111.

60 Loc. cit..

61 Ibid., str. 113.

62 Prema glavi 128. pod nazivom „Knez ne može nikog spriječiti da se obrati dubrovačkom sudu“ namjera je vlade da se posvuda, a osobito na spomenutom otoku, sve stvari objavljuju kako treba i da se glede presuda, i građanskih i krivičnih, na tom otoku moraju poštivati njegovi propisi i stare statutarne odredbe. Zato, ako se katkada dogodi da knez u presuđivanju ne bude htio vladati se i postupati prema propisima te da tako u toj ili u bilo kojoj drugoj stvari bude učinio neku bezočnost ili nanio nepravdu, ne samo sucima nego i bilo kome drugome sa tog otoka, spomenuta gospoda providuri zapovijedaju da svatko može slobodno, kao što je i do sada mogao, doći ovamo žaliti se protiv toga kneza i da taj knez ne može zbog toga ometati ni sprečavati ikoga da pristupi pod (prijetnjom) kazne od 100 perpera u korist dubrovačke blagajne, a ta će ga kazna stići svaki put kada učini taj prekršaj“.

63 Slično ibid, str. 114-115.

64 Kosanović, O., Statut grada Rijeke (1530.), u: Petrović, Z. A. (ur.), Suzbijanje korupcije u Hrvatskoj u srednjem vijeku, Udruga kultura i etika, Zagreb, str. 43.

65 Prijevod Statuta grada Rijeke iz 1530. na latinskom i hrvatskom jeziku sadržan u: Herkov, Z., 
U društveno-političkom kontekstu, gradom Rijekom u 15. stoljeću, u vrijeme grofova Walsee, službu je obnašao kapetan i podkapetan, dok je u doba Habsburgovaca pored kapetana i podkapetana, uveden i zamjenik kapetanu - vikar. ${ }^{66}$ Najviši izraz komunalne samouprave predstavljalo je Veliko vijeće, u kojem je bilo pedeset članova i Malo vijeće sastavljeno od 25 članova Velikog vijeća, s time da se iz redova Malog vijeća birao ili imenovao veliki broj službenika komune. ${ }^{67}$

Poput ostalih srednjovjekovnih statuta priobalnog dijela Hrvatske, i u Riječkom statutu opisi kaznenih djela navedeni su opisno i to prema vanjskim obilježjima djelovanja, dok davanje mita nije regulirano kao posebno kazneno djelo. Međutim, određena ponašanja odgovarala bi u određenim elementima suvremenim konceptima kaznenih djela davanja i primanja mita, kao i zloporabe položaja i ovlasti, iako se, pri analizi statutarnih odredbi, ukazala dvojba radi li se u pojedinom slučaju radi o kaznenoj ili upravnoj regulativi. Ta ponašanja sadržana su u glavama 1., 2., 3., 4., 11. i 19. prve knjige. Karakteristično je za ovaj statut da zabrane navedenih koruptivnih ponašanja nisu locirane na jednom mjestu, te se često nalaze u istoj glavi u kojoj je sadržana i kaznenopravna i upravnopravna materija. ${ }^{68}$

Tako, prema glavi 1. prve knjige, kapetan je u crkvi sv. Vida pred stanovništvom, vijećnicima i sucima trebao prisegnuti, te se, među ostalim, obvezati da će svakome suditi nepristrano i da neće ometati sudovanja vikara ili sudaca, osim ako nije drukčije propisano statutom. I vikar je morao po dolasku u grad prisegnuti svom nadređenom, kao i njegov nadređeni, da će prema svima postupati nepristrano, da neće ometati provođenje presuda te da neće primati mito i varati (glava 2. i 3. Prve knjige). Dakle, ako bi kapetan ili vikar, postupajući suprotno ovim statutarnim odredbama, iskoristio svoj službeni položaj i time sebi ili drugoj osobi pribavio određenu korist ili drugome uzrokovao štetu, tada bi se moglo raditi o svojevrsnom kaznenom djelu zloporabe položaja i ovlasti prema suvremenom pravnom shvaćanju. S druge strane, ako bi kapetan ili vikar zahtijevali ili primili mito da ometaju pravosudni proces, tada bi se radilo o svojevrsnom primanju mita, odnosno ako bi treća osoba dala ili obećala mito ovim visokim javnim „dužnosnicima“ komune, radilo bi se možda o davanju mita.

Statutom, u glavi 19. prve knjige, bilo je određeno da nitko ne smije utjecati (nagovorom ili mitom) na člana Velikog vijeća kada je riječ o izboru člana vijeća ili gradskog službenika. Kazna za takav utjecaj bila je gradirana i ovisila je o statutu "počinitelja": člana Velikog vijeća trebalo je izbaciti iz njega (vijeća) i svih službi na tri godine; a ,počinitelja“ -ne člana Velikog vijeća kažnjavalo se novčanom kaznom u

Statut grada Rijeke iz godine 1530., Nakladni zavod Hrvatske, Zagreb, 1948., str. 119-320 (latinski prijevod) i str. 323-535 (hrvatski prijevod).

66 Kosanović, O., op. cit., str. 43.

67 Ibid., str. 43-44.

68 Iznoseći o osobitosti krivičnog prava ovog statuta Milović je istaknuo da je Riječki statut bio vrlo obiman i obuhvatan pravni kodeks manje-više u svim granama prava, pa tako i u domeni krivičnog prava. Nadalje, isti autor navodi da: „Ipak ni kod njega još uvijek ne nailazimo na odvajanje i posebnu obradu općih krivičnopravnih pojmova i instituta, mada se ovdje po mnogim od tih pitanja ipak nešto osjetnije kročilo naprijed." Vidi u Milović, Đ., Sjeverno-kvarnerski statuti, Zbornik Pravnog fakulteta Sveučilišta u Rijeci, br. 3, 1983., str. 45. 
iznosu od 5 malih libri ili zatvorskom kaznom od 15 dana (jednako je bilo i za muškarce i za žene). ${ }^{69}$ Vidljivo je da predmetna statutarna odredba u sebi sadrži zabranu, ali i kaznu kao jedne od fundamentalnih kaznenopravnih legislativnih elemenata. Štoviše, ponašanje suprotno ovoj stipulaciji društveno je štetno i protupravno, iz čega također proizlazi kaznenopravna priroda ove statutarne odredbe. S obzirom na obilježja ove inkriminacije, u konkretnom bi se slučaju prema postavkama pozitivnoga kaznenog prava, radilo o svojevrsnom kaznenom djelu davanja mita. Kao moguće kazne koje bi se izrekle osuđeniku tog kaznenog djela, statut je predvidio: a) kaznu zatvora, b) novčanu kaznu ili c) (privremenu) zabranu obavljanja javnih službi u trajanju od tri godine. Ovdje valja primijetiti da je statut privremenu zabranu obavljanja djelatnosti regulirao kao jednu od samostalnih (vrsta) kazni, iako bi se, prema suvremenom domaćem konceptu kažnjavanja, radilo o svojevrsnoj dopunskoj sankciji u vidu sigurnosne mjere zabrane obavljanja određene dužnosti ili djelatnosti. ${ }^{70}$ Isto tako, zanimljivo je da je optužbu za sumnju u mito mogao podnijeti svatko s jednim svjedokom i pritom mu je bila zajamčena tajnost, dok je svjedok mogla biti i osoba koju se pokušalo podmititi, pri čemu joj je pripadala jedna trećina kazne po donošenju presude. ${ }^{71}$ Iz analize se može zaključiti da je intencija tvorca statuta bila navedenom odredbom stimulativno djelovati prema osobama prijaviteljima djela podmićivanja, kako zaštitom njihove tajnosti, ali svojevrsnom novčanom naknadom. S tim u vezi odredbe bi predstavljale jedne od prvih odredbi o „Zviždačima“" u hrvatskom kaznenom pravu. Iako, s druge strane, promatrajući s postupovnog aspekta, a imajući u vidu koluzivnost djela podmićivanja, statut je, regulirajući nužnost postojanja jednog svjedoka, postavio visoke pravne „standarde“ potencijalnom prijavitelju ovih djela. Naime, teško je očekivati da bi se davanje mita obavljalo pred svjedocima, budući da bi se, u pravilu, radilo o tajnom korupcijskom „savezu“ između osobe „primatelja“ i „davatelja“ mita.

Najvažniji službenici kapetana i komuna bila su i dva suca, s time da je jednog imenovao kapetan koji je morao biti član Malog vijeća, a drugog Veliko vijeće koji je također obvezno morao biti pripadnik Malog vijeća. ${ }^{72}$ Unutar precizno određenog postupka imenovanja sudaca kancelar komune u određenom stadiju procedure, prilikom izvlačenja listića sa zapisom izbor gospodina suca, tada je vijećnik koji je bio sljedeći u redu morao prisegnuti da na njega nitko nije utjecao ni na koji način (nagovorom ili mitom) te navodno ime kandidata kojeg predlaže za suca (glava 4. knjige prve). ${ }^{73}$

Isto tako, komornici, čiji je preduvjet za posao bila dobra sposobnost računanja, nakon potvrde, morali su prisegnuti da će svoj posao obavljati prema statutu, ne varajući i odnoseći se jednako prema svim dužnicima na jednak način (glava 4. prve knjige).$^{74}$

Vezano uz osiguranje od moguće zloporabe položaja i ovlasti u upravljačkoj

69 Kosanović, O., op. cit., str. 44.

70 Vidjeti i usporedi s čl. 65. i 71. KZ-a.

71 Kosanović, O., op. cit., str. 44-45.

72 Ibid., str. 45.

73 Ibid., str. 45.-46.

74 Ibid., str. 46. 
strukturi indikativna je odredba o satniku (riječ je o jednoj vrsti ondašnjeg glavnog policajca). Naime, prema toj statutarnoj odredbi, po isteku njegova mandata, komornik je u prisutnosti vikara trebao revidirati satnikova primanja, pa ako bi se utvrdilo da je satnik zadržao novac ili štogod od grada, satnik je to morao vratiti. Kazna se kretala u iznosu od 4 soldina po libri, a ako bi se oglušio o odluci o kazni, satnika se moglo izvanredno otpustiti iz službe te njegovu imovinu staviti na javnu dražbu (ako dražba ne bi uspjela, imovina bi trebala pripasti komuni). ${ }^{75}$

I najzad, u skladu s glavom 11. knjige prve, procjenitelji su kao stručnjaci utvrđivali vrijednost pokretnina i nekretnina kada bi to od njih zatražio sud, kako bi se provela ovrha i javna dražba i naplatila šteta, s time da su se morali obvezati da će to učiniti nepristrano i da neće primati mito. ${ }^{76}$ Iz navedene odredbe proizlazi da bi ova inkriminacija po svojim obilježjima imala određene elemente kaznenog djela zloporabe položaja i ovlasti, ali i kaznenog djela primanja mita, u pozitivno pravnom poimanju.

\subsection{Iločka pravna knjiga (Iločki statut)}

Iločki statut je u predvečerje osmanskog osvajanja, 13. prosinca 1525. godine gradu Iloku odobrio kralj Ludovik II. Jagelović. ${ }^{77}$

Sagledavajući strukturalno i sadržajno, Iločki statut sastoji se od pet knjiga koje sadrže ukupno 196 glava ili poglavlja i dva dodatka koja nisu numerirana. ${ }^{78} \mathrm{Na}$ samom početku, prije prve knjige, nalazi se opširni uvodni protokol, a na kraju, nakon pete knjige, završni eshatokol s dignitarijem, koji daju važne informacije o razlozima i okolnostima donošenja Statuta. ${ }^{79}$

Ovim statutom dominiraju norme kaznenog prava, s time da se manji dio tih odredbi nalazi u prvoj i drugoj knjizi, dok je treća knjiga pod naslovom „Rasprave o prolijevanju krvi o kaznama za zlotvore i nasilnike" u cijelosti posvećena kaznenopravnoj regulaciji. ${ }^{80}$ Ta treća knjiga sastoji se od 74 glave u kojima je sadržano oko 60 različitih inkriminacija kažnjivih ponašanja, navedenih uglavnom kazuistički. Valja primijetiti da, u pogledu opisa kaznenih inkriminacija, ovaj statut ne čini iznimku u odnosu na ostale hrvatske srednjovjekovne pravne izvore u kojima nije bila prisutna generalizacija pravnih instituta i djela, već su se inkriminacije sastojale od navođenja konkretnih životnih situacija.

Kaznena djela koja regulira statut mogu se svrstati u nekoliko temeljnih skupina, i to kaznena djela protiv: a) života i tijela, b) spolnih sloboda i spolnog ćudoređa, c) časti i ugleda, d) religije i Crkve, e) imovine, f) sigurnosti, javnog reda i mira te g) protiv pravosuđa. ${ }^{81}$

75 Ibid., str. 46-47.

76 Ibid., str. 47.

77 Tomičić, Z., Iločki statut i njegova kaznenopravna regulacija, Hrvatsko udruženje za kaznene znanosti i praksu, MUP RH, Zagreb, 2006., str. 15.

78 Ibid., str. 21.

79 Ibid., str. 21-26.

80 Ibid., str. 47.

81 Ibid., str. 78. 
Što se tiče koruptivnih ponašanja, treba izdvojiti dvije inkriminacije koje bi ulazile u skupinu statutarnih kaznenih djela protiv pravosuđa: a) kažnjavanje „lažnih““ zastupnika (treća knjiga, glava 59.) i b) kažnjavanje sudaca (treća knjiga, glava 66.). Po svojim obilježjima, ova bi djela, imajući u vidu pozitivnu kaznenu regulaciju u hrvatskom pravnom sustavu, sadržavale elemente kaznenog djela zloporabe položaja i ovlasti. ${ }^{82}$ Naime, u glavi 59., predviđeno je kažnjavanje lažnih zastupnika koji u parnici namjerno loše zastupaju pravednoga i navode postupak na štetu osobe koju zastupaju. ${ }^{83}$ Prema glavi 66. sudac koji bi svojevoljno otpustio ubojicu, dužan je oštećenoj strani platiti homagij odnosno vraždu i gubi sudačku funkciju ${ }^{84}$ Važno je istaknuti da Iločki statut nije sadržavao odredbe kojima bi bilo regulirano aktivno podmićivanje.

Kao svrhe kažnjavanja u Iločkom statutu mogu se pronaći elementi generalne i specijalne prevencije, kao i elemente zadovoljenja, kako materijalne naknade, tako i zadovoljenja osvetničkih osjećaja. ${ }^{85} \mathrm{U}$ vezi s tim, Tomičić, zaključuje da, s obzirom na to da statutom dominira smrtna kazna, specijalna se prevencija pojavljuje uglavnom u svom najprimitivnijem obliku, fizičkoj eliminaciji počinitelja.

Od kazni, statut predviđa: smrtnu kaznu, tjelesnu kaznu, novčanu kaznu, kaznu progona, stigmatizaciju, kaznu pogrde i neka dodatna pooštrenja kazne. ${ }^{86}$

\subsection{Zlatna bula (Povlastica Bele IV. Gradecu)}

Iz do sada elaboriranog proizlazi da u gradovima koji su se nalazili u priobalnom dijelu Hrvatske nalazimo u pravilu statute kao oblik ujedinjavanja i sistematizacije u jednu cjelinu srednjovjekovnih pravnih normi koje su bile na snazi, dok su u sjevernom dijelu srednjovjekovne pravne norme sadržane $u$ ispravama nazvanim kraljevskim povlasticama, tzv. bule, kojima bi kralj osnivao pojedini grad, dodjeljujući mu povlastice. ${ }^{87}$ Predmet obrade u ovom dijelu bit će jedan od tih povlastica, Zlatna bula ili Povlastica (Privilegij) kralja Bele IV. koja je dodijeljena 16. studenoga 1242. godine zagrebačkom Gradecu. ${ }^{88}$ Ovim je Gradec postao slobodni kraljevski grad.

Bula je pisana na latinskom jeziku koji je bio svojevrsni službeni jezik $\mathrm{u}$ uporabi u ispravama srednjovjekovne Europe ${ }^{89}$ Važan dio Bule obuhvaća norme kaznenog prava koje se ponajprije odnose na kaznena djela, kazne i sudski postupak. ${ }^{90}$

82 Usporedi s čl. 291. KZ-a.

83 Tomičić, Z., op. cit., str. 106.

84 Ibid., str. 107.

85 Ibid., str. 68.

86 Ibid., str. 69.

87 Tako i Latković, B., Zlatna bula iz 1242. Gradec - srednjovjekovno porijeklo Zagreba, HAZU, Rijeka, 2005. str. 21.-22.

88 U daljnjem tekstu: Bula. Nakon upada Mongola u Ugarsku i Hrvatsku 1241. hrvatsko-ugarski kralj Bela IV. uvidio je da je nužno utvrditi granicu svog kraljevstva, zbog čega je osnovao na zapadu Hrvatske grad povlasticom, odnosno Zlatnom bulom ili Bula aurea. U samoj Buli kralj je kazao da je odlučio osnovati slobodni grad u Zagrebu na brdu Grič - preuzeto iz Latković, B., op. cit., str. str. 55.

89 Ibidr. str. 77.

90 Ibid., str. 89. 
Analizirajući Bulu, Margetić i Apostolova Maršavelski zaključili su da ovaj privilegij predstavlja jedini (najopširniji) kraljevski privilegij u čijem je tekstu ugrađen popis pravnih normi koje se odnose na kazneno pravo i uređenje funkcioniranja gradskog suda. ${ }^{91}$

U prvom redu spominju se kaznena djela napada kao pogrda, osramoćenje, povreda i neke druge manje teške, kao pljuska ili navlačenje kose, dok u drugoj skupini normi prevladavaju prijestupi kao što su fizički napadi učinjeni sredstvima koja bi mogla povrijediti do smrti (nož, mač, koplje, strijela i slično). Uz spomenuto, Bula se bavi i krađom ili oduzimanjem „konja, vola ili neke druge stvari“ učinjenom po domaćem stanovniku ili strancu. ${ }^{92} \mathrm{~S}$ materijalno pravnog aspekta, važno je navesti da su opisi kaznenih djela u Buli stipulirani kazuistički; da odredbe Bule nisu svjedočile o institutu krivnje, već je za počinjenje djela dostatan objektivni i vanjski kriterij počinjenja djela te da su propisane kazne pretežno novčane.

U Gradecu je sudsku vlast obnašao gradski sudac. Zanimljivo je da su građani imali pravo slobodno birati gradskog suca odakle god hoće, mijenjajući ga svake godine po svojoj volji, s time da je ta sloboda bila ograničena povlasticom iz 1266. godine, prema kojoj je bilo zabranjeno za gradskog suca izabrati osobu koja je osuđena zbog lažnog svjedočenja. ${ }^{93}$ Ako gradski sudac bude sumnjiv i tužitelj navede zakonite razloge za njegovo odbijanje (svojevrsno izuzeće ili otklon), prema Buli, neka se sazovu svi stariji građani i u nazočnosti istog suca odluče o pravnoj stvari. A ako se bude sumnjalo i u njihovu odluku i ako ih bezobzirni tužitelj pozove pred kralja, sam sudac za sve ostale treba ići pred kralja.

$\mathrm{S}$ aspekta predmetne problematike, analizom privilegiranih odredbi, moglo bi se reći da Bula ne sadrži kaznene norme koje bi neposredno ili posredno svjedočile o (aktivnom) podmićivanju.

\section{ZAKLJUČAK}

Sagledavajući obrađene izvore hrvatskoga srednjovjekovnog prava, valja izdvojiti nekoliko temeljnih obilježja s aspekta regulacije kažnjavanja aktivnog podmićivanja.

Prvo, s pravno-tehničkog aspekta, statutarne odredbe analiziranih „kodifikacija“ nisu bile posebno razrađene i odijeljene po pojedinim pravnim područjima. To je dovelo do otežane analize ovih normativa, jer u nekim slučajevima nije bilo moguće bez sumnje utvrditi radi li se o kaznenoj ili građanskoj ili upravnoj regulaciji. S tim u vezi nije se sa izvjesnošću moglo razabrati radi li se o kaznenom djelu i kažnjavanju počinitelja u kaznenopravnom smislu ili stegovnoj kazni ili upravnoj mjeri koje su dio stegovnog ili upravnog postupka.

Drugo, imajući u vidu kompoziciju i usustavljenost hrvatski srednjovjekovni

91 Margetić, L., Apostolova Maršavelski, M.; Hrvatsko srednjovjekovno pravo (vrela s komentarom), Narodne novine, Zagreb, 1999., str. 62.

92 Ibid., str. 91.

93 Tako Margetić, L., Apostolova Maršavelski, M., Hrvatsko srednjovjekovno pravo (vrela s komentarom), Narodne novine, Zagreb, 1999., str. 65. i Latković, B., Zlatna bula iz 1242. Gradec - srednjovjekovno porijeklo Zagreba, HAZU, Rijeka, 2005., str. 95. 
normativi, u pravilu su predstavljali jedan više-manje mehanički zbroj raznih pravnih propisa, među kojima se nalaze i brojne odredbe o kaznenim djelima i kaznama, uvrštene bez ikakvog pravnog sustava.

Treće, hrvatsko srednjovjekovno pravo pretežno je bilo analitičko i kazuističko. To znači da se za svaki pojedini slučaj i prema vanjskim obilježjima određivala posebna norma, što se odnosi i na opise pojedinih kaznenih djela, pa i djelapodmićivanja.

Četvrto, premda obiluju normama kaznenog prava čija je svrha bila spriječiti i suzbiti zloporabu položaja i ovlasti te podmićivanje, ali i druge pojavne oblike koruptivnog ponašanja, srednjovjekovni normativi, u pravilu, nisu sadržavali odredbe koje bi svjedočile o aktivnom podmićivanju kao posebnom kaznenom djelu. Unatoč tomu, ti su normativi sadržavali određena ponašanja (inkriminacije) koja bi odgovarala suvremenim konceptima kaznenih djela davanja i primanja mita, kao i zloporabe položaja i ovlasti.

Peto, u normativnom dijelu promatranih kodifikacija, u pravilu, nema odredbi koje bi neposredno svjedočile o poimanju svrhovitosti kažnjavanja toga vremena. Iznimku od toga predstavlja Iločki statut, ali i djelomično i „u tragovima“ Splitski i Korčulanski statut.

I krajnje, šesto, od propisanih kazni za kaznena djela podmićivanja, ističu se, ponajprije novčana kazna i zabrana obavljanja dužnosti ili službe.

\section{LITERATURA}

1. Anić Š., Klarić N., Domović, Ž., Rječnik stranih riječi, Zagreb, Sani-plus, 2002.

2. Bačić, F., Krivično pravo - Opći dio, Zagreb, Informator, 1995.

3. Cvitanić, A. (prir. i prev.), Šeparović, Z. (ur.), Korčulanski statut: Statut grada i otoka Korčule iz 1214., Zagreb - Korčula, JAZU, Jugoslavenska akademija znanosti i umjetnosti: Pravni fakultet: Grafički zavod Hrvatske; Split: Pravni fakultet; Korčula: Skupština općine, 1987.

4. Cvitanić, A., Pristav u Vinodolskom zakonu, Zbornik Pravnog fakulteta Sveučilišta u Rijeci, vol. 3, (1982), str. 69-74.

5. Cvitanović, L., Svrha kažnjavanja u suvremenom kaznenom pravu (disertacija), Zagreb, Pravni fakultet u Zagrebu, 1997.

6. Dragičević Prtenjača, M., Lastovski statut u Petrović, Z. A. (ur.), Suzbijanje korupcije u Hrvatskoj u srednjem vijeku, Zagreb, Udruga Kultura i etika, 2014.

7. Galović, T., Vinodolski zakon, u: Petrović, Z. A. (ur.), Suzbijanje korupcije u Hrvatskoj u srednjem vijeku, Zagreb, Udruga Kultura i etika, 2014.

8. Herkov, Z., Statut grada Rijeke iz godine 1530., Zagreb, Nakladni zavod Hrvatske, 1948.

9. Janeković Romer, Z., Dubrovački statut i druge zakonske zbirke, u: Petrović, Z. A. (ur.), Suzbijanje korupcije u Hrvatskoj u srednjem vijeku, Zagreb, Udruga Kultura i etika, 2014.

10. Kosanović, O., Statut grada Rijeke (1530.), u: Petrović, Z. A. (ur.), Suzbijanjekorupcije u Hrvatskoj u srednjem vijeku, Udruga Kultura i etika, Zagreb, 2014.

11. Lonza, N. (ur.), The Statute of Dubrovnik od 1272., Dubrovnik, Državni arhiv u Dubrovniku, 2012.

12. Šoljić, A., Šundrica, Z. i Veselić, I. (pre. i ur.), Statut grada Dubrovnika (sastavljen godine 1272.), Dubrovnik, Državni arhiv u Dubrovniku, 2002.

13. Prijatelj, K. (ur.), Statut grada Trogira, Split, Književni krug, 1995.

14. Radić, Ž., Korčulanski statut, u: Petrović, Z. A. (ur.), Suzbijanje korupcije u Hrvatskoj u srednjem vijeku, Zagreb, Udruga Kultura i etika, 2014. 
15. Rismondo, V. (ur.), Lastovski statut, Split, Književni krug, 1994.

16. Statut grada Splita, Frangeš, I. (ur.), Split, Književni krug Split, 1998.

17. Rismondo V. (ur.), Statut grada Splita: srednjovjekovno pravo Splita, Split, Književni krug, 1985.

18. Statuti primorskih gradova i općina, Jugoslavenska akademija znanosti i umjetnosti, Zagreb, 1911., <booksnow1.scholarsportal.info/.../statutiprimorski00stro/ statutiprimorski00stro.pdf $>, 20$. studeni 2016.

19. Strohal, I. (nap.), Statuti primorskih gradova i općina, Jugoslavenska akademija znanosti i umjetnosti, Zagreb, 1911., <booksnow1.scholarsportal.info/.../statutiprimorski00stro/ statutiprimorski00stro.pdf $>, 20$. studeni 2016.

20. Šilović, J., O razvoju krivnje u hrvatskom kaznenom pravu, Zagreb, JAZU, 1912.

21. Tomičić, Z., Iločki statut i njegova kaznenopravna regulacija, Hrvatsko udruženje za kaznene znanosti i praksu, Zagreb, MUP RH, 2006.

22. Korčulanski statut. Statut grada i otoka Korčule iz 1214. godine, Arhivski vjesnik, vol. 31, 1987., str. 175-192.

23. Latković, B., Zlatna bula iz 1242. Gradec - srednjovjekovno porijeklo Zagreba, Rijeka, HAZU, 2005.

24. Margetić, L., Apostolova Maršavelski, M., Hrvatsko srednjovjekovno pravo (vrela s komentarom), Zagreb, Narodne novine, 1999.

25. Hrvatska enciklopedija, <www.enciklopedija.hr>, 20. studeni 2016.

26. Vrhovni sud Republike Hrvatske, $<$ www.vsrh.hr/EasyWeb.asp?pcpid=337>, 20. studeni 2016.

27. HKD Novosti, <www.hkdrustvo.hr/hkdnovosti/../595>, 20. studeni 2016. 
Summary

\section{ACTIVE BRIBERY IN CROATIAN MEDIEVAL AND MODERN LAW}

When it comes to writing about the history of punishment, it is always linked with critically re-thinking and better understanding of the contemporary system of punishment, as a result of its long historical development. In such a way, „contemporary criminal law cannot be seen as a result of an effort made by a certain nation or in a certain epoch“. „Permanently faced with social changes, in its long historical development, criminal law has been modifying its fundamental principles and categories, by building new institutes and instruments, in order to become less cruel and more human, but not less efficient than in earlier stages of its development, characterized by rudeness, cruelty and exemplarity of its sanctions.

Although it is not easy to answer the question, if there is the measure, in which social understanding of punishment and its purpose, determines the civilizational level in the society, there is no doubt about the fact that civilizational and legal point of view towards punishment derives from a waste range of factors: general, cultural, sociological, psychological, religious, political and other factors that should be taken altogether in their historical dimension.

The genesis of criminal law is linked with the moment of establishing the public authorities and the state. According to different criteria, it is possible to introduce different periodization of criminal law. When it comes to the historical criterion, there can be made a historical division into periods of ancient, medieval, modern and contemporary criminal law (punishment), which periods should not be taken as absolutely inseparable. The point of this paper is to present a review and development of punishing active bribery in the Croatian medieval and modern law.

Keywords: Middle Ages, Modern Age, a gift, bribe, benefit, corruption, bribery, punishment, the purpose of punishment, punishment, imprisonment, fine.

\section{Zusammenfassung}

\section{AKTIVE BESTECHUNG IM KROATISCHEN MITTELALTERLICHEN UND MODERNEN RECHT}

Wenn es um die Geschichte der Strafe geht, ist sie immer mit dem kritischen Umdenken und dem besseren Verständnis des zeitgenössischen Bestrafungssystem, als einem Ergebnis der langen historischen Entwicklung, verbunden. Im Bezug dazu kann „das moderne Strafrecht nicht als Ergebnis einer Anstrengung einer bestimmten Nation oder einer bestimmten Epoche gesehen werden". Wegen dem ständigen Umgang mit dem gesellschaftlichen Wandel hat das Strafrecht in seiner langen 
geschichtlichen Entwicklung seine grundlegenden Prinzipien und Kategorien durch den Aufbau neuer Institute und Instrumente verändert, um weniger grausam und mehr menschlich zu werden, dabei aber nicht weniger effizient als in früheren Stadien seiner Entwicklung zu sein, die durch Unhöflichkeit, Grausamkeit und Vorbildlichkeit der Sanktionen gekennzeichnet wurde.

Obwohl es nicht leicht ist, die Frage zu beantworten, ob es eine Maßnahme gibt, dessen soziale Verständnis von Strafe und deren Zweck die zivilisatorische Ebene in der Gesellschaft bestimmt, besteht kein Zweifel daran, dass zivilisatorische und rechtliche Gesichtspunkte der Strafe ein Resultat folgender Faktoren sind: allgemeinen, kulturellen, soziologischen, psychologischen, religiösen, politischen und anderen Faktoren, die in ihrer historischen Dimension als eine Einheit betrachtet werden sollen.

Die Entstehung des Strafrechts ist mit der Gründung der Behörden und des Staates verbunden. Anhand verschiedener Kriterien ist es möglich, eine unterschiedliche Periodisierung des Strafrechts einzuführen. Wenn es um das historische Kriterium geht, kann eine historische Aufteilung ins Zeitalter des antiken, mittelalterlichen, modernen und zeitgenössischen Strafrechts (Strafe) erfolgen, die nicht als absolut untrennbar betrachtet werden sollen. Das Ziel dieser Arbeit ist es, eine Überprüfung und Entwicklung der Bestrafung aktiver Bestechung im kroatischen mittelalterlichen und modernen Recht zu präsentieren.

Schlüsselwörter: Mittelalter, Moderne, Geschenk, Bestechung, Nutzen, Korruption, Strafe, Zweck der Strafe, Gefängnis, Geldbuße.

Riassunto

\section{LA CORRUZIONE ATTIVA NEL DIRITTO CROATO MEDIEVALE E MODERNO}

Scrivere delle storia della punibilità significa, in realtà, riflettere, mettere in discussione criticamente e comprendere meglio il sistema contemporaneo della punibilità, il quale è proprio il risultato di una lunga evoluzione storica. Precisamente, „l'attuale diritto penale non è il risultato degli sforzi di un'epoca o di una nazione". „Scontrandosi con i cambiamenti nella società, il diritto penale ha modificato nel corso del tempo il contenuto dei propri precetti di base e delle proprie categorie; ha costruito nuovi istituti giuridici e strumenti, divenendo con il tempo meno spietato e più umano, senza che ciò ne sminuisca l'efficacia in confronto a quelle fasi in cui fu caratterizzato da ferocia, spietatezza ed esemplarità delle sanzioni penali““.

E' arduo rispondere in quale misura l'idea di punizione, ossia della pena e della sua funzione, definisca oppure possa definire il livello di civiltà di una singola società; tuttavia, è del tutto certo che le presa di posizione sotto il profilo della civilizzazione e sotto quello giuspenalistico nei confronti della pena si fonda su numerosi presupposti: fattori generali, culturali, sociologici, psicologici, religiosi, politici ed altri fattori che 
vanno considerati anche nella loro dimensione storica.

Il momento stesso della nascita del diritto penale viene collegato con il momento della creazione del potere pubblico e dello stato. In base a diversi criteri si può suddividere diversamente il diritto penale per periodi storici. Tuttavia, in chiave storica vanno distinti il periodo del diritto penale antico, medievale, moderno e contemporaneo; sebbene tali periodi non vanno distinti in maniera assoluta. In questo lavoro si tenterà di offrire una rassegna e l'evoluzione della punibilità dell'autore della corruzione attiva nel diritto croato medievale.

Parole chiave: medioevo, età moderna, dono, tangente, vantaggio, corruzione, punizione, scopo della punizione, pena, pena di detenzione, pena pecuniaria. 
